\title{
Erratum: Association between knowledge of caries preventive practices, preventive oral health habits of parents and children and caries experience in children resident in sub-urban Nigeria
}

Morenike O Folayan ${ }^{1,2,3 *}$, Kikelomo A Kolawole ${ }^{1,2,3 \dagger}$, Titus Oyedele ${ }^{2,3+}$, Nneka M Chukwumah ${ }^{2,3+}$, Nneka Onyejaka ${ }^{2,3 \dagger}$, Hakeem Agbaje ${ }^{2,3+}$, Elizabeth O Oziegbe ${ }^{1,2,3+}$ and Olusegun V Oshomoji ${ }^{2,3+}$

\section{Erratum}

After publication of this research article [1], we noticed a mistake in the names of two of the authors. Olusegun V Osho name should be Olusegun V Oshomoji, and Nneka M Chukumah name should be Nneka M. Chukwumah. This has been now corrected. We apologise for any inconvenience.

\section{Author details}

'Department of Child Dental Health, Obafemi Awolowo University, lle-lfe, Nigeria. ${ }^{2}$ Oral Habit Study Group, Ile-lfe, Nigeria. ${ }^{3}$ Department of Child Dental Health, Obafemi Awolowo University Teaching Hospitals Complex, Ile-lfe, Nigeria.

Received: 11 February 2015 Accepted: 17 February 2015

Published online: 20 May 2015

\section{Reference}

1. Folayan MO, Kolawole KA, Oyedele T, Chukumah NM, Onyejaka N, Agbaje H, et al. Association between knowledge ofcaries preventive practices, preventive oral health habits of parents and children and caries experience in children resident in sub-urban Nigeria. BMC Oral Health. 2014;14:156.

\footnotetext{
* Correspondence: toyinukpong@yahoo.co.uk

${ }^{\dagger}$ Equal contributors

'Department of Child Dental Health, Obafemi Awolowo University, lle-lfe, Nigeria

${ }^{2}$ Oral Habit Study Group, Ile-Ife, Nigeria

Full list of author information is available at the end of the article
}

Submit your next manuscript to BioMed Central and take full advantage of:

- Convenient online submission

- Thorough peer review

- No space constraints or color figure charges

- Immediate publication on acceptance

- Inclusion in PubMed, CAS, Scopus and Google Scholar

- Research which is freely available for redistribution

Submit your manuscript at www.biomedcentral.com/submit 